Global Conferences Series:

Social Sciences, Education and Humanities (GCSSSEH), Volume 6, 2020

International Conference Fakultas Tarbiyah dan Keguruan Universitas Islam Negeri Imam Bonjol Padang (ICFTKUINIBP) 2020

DOI: https://doi.org/10.32698/icftk424

\title{
Contribution of Learning Model Student Teams Achievement Division in Understanding Mathematical Concepts
}

\section{Kontribusi Model Pembelajaran Student Teams Achievement Division dalam Pemahaman Konsep Matematis}

\author{
Andi Susanto ${ }^{\mathbf{a}}$, Martin Kustati ${ }^{\mathbf{a}}$, Noventa Eli Yusna ${ }^{\mathbf{a}}$ \\ ${ }^{a}$ Fakultas Tarbiyah dan Keguruan, Universitas Islam Negeri Imam Bonjol, Padang, Indonesia \\ E-mail: andisusanto@uinib.ac.id
}

\begin{abstract}
This study aims to reveal the contribution of the student achievement division (STAD) type cooperative learning model in developing students ability to understand mathematical concepts. This is done based on studies which state that the application of the STAD learning model improves students ability to understand mathematical concepts, but has not revealed in detail this model in developing each indicator of understanding mathematical concepts. This research is a literature study that discusses the syntax of STAD learning models and indicators of understanding mathematical concepts. The results showed that the six-step STAD learning model provided opportunities and was able to make student learning activities increase in developing their ability to understand mathematical concepts, it can be concluded that the STAD learning model contributes in developing students ability to understand mathematical concepts,
\end{abstract}

Keywords: Understanding of mathematical concepts, STAD learning model

\section{PENDAHULUAN:}

Pemahaman Konsep merupakan aspek yang sangat penting dalam pembelajaran matematika. Pemahaman konsep matematika adalah mengerti benar tentang konsep matematika, yaitu peserta didik dapat menerjemahkan, menafsirkan, dan menyimpulkan suatu konsep matematika berdasarkan pembentukan pengetahuannya sendiri, bukan sekedar menghafal. Selain itu peserta didik dapat menemukan dan menjelaskan kaitan konsep dengan konsep yang lainnya. Dengan memahami konsep, peserta didik dapat mengembangkan kemampuannya dalam pembelajaran matematika, peserta didik dapat menerapkan konsep yang telah dipelajari untuk menyelesaikan permasalahan sederhana sampai dengan yang kompleks.

Pentingnya pemahaman konsep matematika terlihat dalam tujuan pertama pembelajaran matematika menurut Depdiknas (Permendiknas No 22 tahun 2006) yaitu memahami konsep matematika, menjelaskan keterkaitan antar konsep dan mengaplikasikan konsep atau algoritma secara luwes, akurat, efisien dan tepat dalam pemecahan masalah. Hal ini sesuai dengan tujuan pembelajaran matematika, maka setelah proses pembelajaran peserta didik diharapkan dapat memahami suatu konsep matematika sehingga dapat menggunakan kemampuan tersebut dalam menghadapi masalah-masalah matematika. Jadi dapat dikatakan bahwa pemahaman konsep merupakan bagian yang paling penting dalam pembelajaran matematika. Oleh karena itu peserta didik harus memahami konsep matematika terlebih dahulu agar dapat menyelesaikan soalsoal dan mampu mengaplikasikan pembelajaran tersebut dalam dunia nyata. Namun masih banyak peserta didik yang kurang mampu memahami konsep dalam pembelajaran matematika. Salah satu penyebab rendahnya kemampuan pemahaman konsep matematis peserta didik adalah tidak tepatnya pendidik dalam memilih Metode maupun Model pembelajaran yang mampu meningkatakan pemahaman konsep matematis peserta didik itu sendiri. Pendidik hanya suka-suka dalam memilih model pembelajaran dan belum menunjukan kemampuan yang akan dituju.

Beberapa model pembelajaran digunakan di kelas dengan tujuan untuk meningkatkan pemahaman terhadap konsep dalam matematika. Upaya-upaya dengan mengganti atau menggunakan model pembelajaran

Copyright (C) 2020, the Authors. Published by Redwhite Press.

Page | 209

This is an open access article under the CC BY-NC license

(http://creativecommons.org/licenses/by-nc/4.0). 
disesuaikan dengan materi atau jenis pelajarannya. salah satu model pembelajaran yang dapat digunakan untuk meningkatkan kemampuan pemahaman konsep yaitu menggunakan model STAD.

Model Pembelajaran STAD merupakan salah satu model pembelajaran kooperatif dengan menggunakan kelompok-kelompok kecil dengan jumlah anggota tiap kelompok 4-5 siswa secara heterogen, yang merupakan campuran menurut tingkat prestasi, jenis kelamin, dan suku. Diawali dengan penyampaian tujuan pembelajaran, penyampaian materi, kegiatan kelompok, kuis, dan penghargaan kelompok (Trianto, 2017). Manfaat model pembelajaran kooperatif tipe STAD untuk siswa dalam jangka pendek siswa mempelajari isi materi pelajaran yang sedang dibahas. Kemudian Adanya anggota kelompok lain yang menghindari kemungkinan siswa mendapat nilai rendah, karena dalam tes lisan siswa dibantu oleh anggota kelompoknya. Pembelajaran kooperatif menjadikan siswa mampu belajar berdebat, belajar mendengarkan pendapat orang lain, dan mencatat hal-hal yang bermanfaat untuk kepentingan bersama-sama, Pembelajaran kooperatif menghasilkan pencapaian belajar siswa yang tinggi menambah harga diri siswa dan memperbaiki hubungan dengan teman sebaya, hadiah atau penghargaan yang diberikan akan memberikan dorongan bagi siswa untuk mencapai hasil yang lebih tinggi, Siswa yang lambat berpikir dapat dibantu untuk menambah ilmu pengetahuan, dan Pembentukan kelompok-kelompok kecil memudahkan guru untuk memonitor siswa dalam belajar bekerja sama (Soewarso, 1998).

Model STAD selain unggul dalam membantu siswa memahami konsep-konsep sulit, model ini juga sangat berguna untuk membantu siswa, menumbuhkan kemampuan, dan kemampuan membantu teman (Handayani, 2019). Jadi dari uraian diatas terlihat bahwa model pembelajaran kooperatif tipe STAD adalah salah satu alternatif untuk meningkatkan pemahaman konsep peserta didik peserta didik serta mampu membuat peserta didik menjadi lebih aktif. Ini sesuai dengan hasil dari beberapa penelitian terdahulu.

Berdasarkan hasil temuan Murnaka dan Rika Itho Manalu yang dilakukan pada tahun 2018 dalam jurnalnya menjelaskan bahwa Model pembelajaran kooperatif tipe STAD dapat meningkatkan kemampuan pemahaman konsep matematis siswa. Hal ini dikarenakan kerjasama antar siswa dapat memantapkan kemampuan pemahaman konsep matematis pada diri siswa, karena dengan belajar bersama akan terjadi sharing pengetahuan dan keterampilan (Munarka, 2018). Ini dibuktikan dengan hasil penelitiannya bahwa peningkatan kemampuan pemahaman konsep matematis siswa yang menggunakan model pembelajaran kooperatif tipe STAD lebih tinggi dari pada siswa yang menggunakan pembelajaran konvensional.

Berdasarkan hasil temuan Nesha Aprilia Puspa, Sugeng Sutiarso, dan Rini Asnawati dalam jurnalnya pada tahun 2019, mengatakan bahwa dalam proses pembelajaran siswa masih berperan secara pasif. Siswa hanya mencatat mendengarkan materi yang diberikan oleh guru. Metode pembelajaran ekspositori, yaitu situasi pembelajaran yang menggambarkan kegiatan guru aktif memben informasi, sedangkan kegiatan siswa menyimak, mencatat, dan mengerjakan tugas. Meskipun guru tidak terus menerus bicara, namun proses ini menekankan penyampaian tekstual dan kurang mengembangkan kemampuan belajar matematika siswa. Kebiasaan siswa bersikap pasif dalam pembelajaran dapat mengakibatkan sebagian besar siswa takut dan malu bertanya pada guru mengenai materi yang kurang dipahami (Puspa, 2018).

Penggunaan model pembelajaran kooperatif merupakan salah satu alternatif untuk meningkatkan pemahaman siswa dan mampu membuat siswa menjadi lebih aktif. Pembelajaran kooperatif menekankan kerjasama antar siswa dalam kelompok untuk mencapai tujuan pembelajarannya. Berdasarkan penelitiannya dapat disimpulkan bahwa pemahaman konsep matematika siswa yang menggunakan model pembelajaran kooperatif tipe STAD berpengaruh positif terhadap hasil belajar dan membentuk cara berfikir siswa agar lebih mudah memahami serta kritis terhadap mata pelajaran matematika.

Selanjutnya berdasarkan penelitian yang dilakukan oleh Yanuar, Klara Iswara Sukmawati, dan Samsul Arifin pada tahun 2019, menyatakan bahwa untuk Menyikapi rendahnya kemampuan pemahaman konsep matematis siswa maka dibutuhkan model pembelajaran yang tepat, salah satunya model pembelajaran kooperatif tipe STAD. Menurut Alim et al (2013) dengan pembelajaran STAD akan tercipta pembelajaran yang dapat meningkatkan motivasi belajar, dan kondisi belajar yang menyenangkan, maka siswa dapat saling bekerja sama dalam menguasai suatu konsep pembelajaran, sehingga pamahaman konsep matematis siswa dapat di tingkatkan. Hal ini sejalan dengan Putra et al (2015) dimana melalui pembelajaran STAD siswa didorong untuk melakukan tukar-menukar (Sharing) informasi, pendapat, mendiskusikan permasalahan secara bersama, membandingkan jawaban teman, dan mengoreksi hal-hal yang kurang tepat sehingga dapat memahami suatu konsep dengan baik dan benar. Hasil dari penelitiannya mendapatkan kesimpulan bahwa model pembelajaran STAD dapat menigkatkan kemapuan pemahaman konsep matematis siswa (Yanuar, 2019).

Berdasarkan hasil temuan Ari Septian, Deby Agustina, dan Destysa Maghfirah dalam jurnalnya pada tahun 2020, dalam kegiatan belajar mengajar peristiwa yang sering terjadi adalah kurangnya pemahaman siswa terhadap konsep matematika dan kurangnya keterampilan guru dalam menyampaikan materi 
pembelajaran, sehingga siswa bingung bagaimana cara menyelesaikan soal dan untuk apa sebenarnya mereka belajar matematika. Kesulitan belajar matematika akan dapat diselesaikan dengan cara memperbaharui cara mengajar guru kepada siswanya. Hasil temuan dari penelitian yang dilakukan oleh Ari Septian, Deby Agustina, dan Destysa Maghfirah adalah Penerapan model pembelajaran kooperatif tipe STAD dapat meningkatkan pemahaman konsep matematika siswa, aktivitas siswa sangat baik terhadap pembelajaran matematika dengan menggunakan model pembelajaran kooperatif tipe STAD dan sikap siswa positif terhadap pembelajaran matematika dengan menggunakan model pembelajaran kooperatif tipe STAD (Septian, 2020).

Dari berbagai hasil penelitian eksperimen yang dilakukan oleh beberapa peneliti terdahulu menyatakan bahwa model pembelajaran STAD dapat meningkatkan kemampuan pemahaman konsep matematis. Tetapi pada beberapa penelitian terdahulu belum ada yang menjelaskan secara spesifik kontribusi setiap langkah-langkah model pembelajaran STAD pada kemampuan pemahaman konsep matematis, sehingga tujuan dari penelitian ini adalah untuk mengetahui bagaimana kontribusi model pembelajaran kooperatif tipe STAD terhadap kemampuan pemahaman konsep matematis.

\section{METODE}

Jenis penelitian ini adalah penelitian kepustakaan (Library Reasearch). Data pada penelitian ini ada dua yaitu data primer dan data sekunder. Data primer pada penelitian ini adalah teori tentang model STAD yang diuangkapkan oleh Slavin dan teori tentang kemampuan pemahaman konsep yang diungkapkan oleh Permendikbud No 58 tahun 2014. Kemudian data sekunder yang di gunakan dalam penelitian ini adalah jurnal-jurnal maupun artikel yang berkaitan dengan model STAD dan pemahaman konsep matematis.

Sumber data pada penelitian ini adalah buku-buku literatur tentang teori belajar, model pembelajaran STAD, strategi belajar mengajar dan lain sebagainya. Kemudian sumber data pada penelitian ini adalah jurnal-jurnal online yang ada di Google scholar, Scopus, Mendeley dan lain sebagainya.

Teknik pengumpulan data yang digunakan adalah studi literatur yaitu dengan mengumpulkan Bahanbahan pustaka berupa indikator pemahaman konsep yang terdapat pada peraturan kementrian pendidikan dan kebudayaan nomor 58 tahun 2014, sintak model pembelajaran kooperatif dan sintak pembelajaran kooperatif tipe STAD yang di dapat dari buku Trianto yang berjudul Mendesain model pembelajaran inovatifprogresif. Kemudian langkah-langkah pembelajaran kurikulum 2013 yang di dapat dari Hamzah h Yunus dan Heldy Vanni Alam yang berjudul Perencanaan Pembelajaran Berbasis Kurikulum 2013.

Teknik Pengolahan Data dalam penelitian ini diolah dengan cara :

Editing, penulis menetapkan sumber mana yang paling mendukung terhadap penelitian, seperti indikator-indikator pemahaman konsep, model pembelajaran kooperatif dan model pembelajaran kooperatif tipe STAD, dan langkah-langkah pembelajaran kurikulum 2013.

Organizing, Dalam penelitian ini penulis melakukan penyusunan data yang dimulai dari memaparkan langkah pembelajaran kurikulum 2013, sintak pembelajaran STAD, kemudian gabungan pembelajaran kurikulum 2013 dengan sintak STAD dan yang terakhir gabungan model pembelajaran STAD dan kurikulum 2013 yang dikaitkan dengan indikator pemahaman konsep.

Penemuan hasil penelitian, Dalam penelitian ini penulis melakukan analisis lanjutan terhadap hasil penyusunan data yang telah disebutkan diatas dengan menggunakan teori pendukung dan metode penelitian kepustakaan yang sudah dijelaskan sebelumnya.

Analisis data yang digunakan dalam penelitian ini dilakukan secara induktif, untuk memberikan gambaran yang tepat mengenai hal-hal yang sebenarnya terjadi. Metode induktif yaitu cara menganalisis data yang berangkat dari fakta-fakta atau peristiwa-peristiwa konkrit yang telah dikumpulkan untuk ditarik kesimpulan secara umum. Disini penulis mengumpulkan jurnal-jurnal, buku-buku maupun artikel yang berkaitan dengan model pembelajaran kooperatif tipe STAD dan kemampuan pemahaman konsep matematis, kemudian di tarik kesimpulan dari beberapa jurnal tersebut.

\section{HASIL DAN PEMBAHASAN \\ Hasil \\ Pembelajaran kurikulum 2013}

Pembelajaran kurikulum 2013 terbagi menjadi tiga kegiatan yaitu, (a) kegiatan pendahuluan; (b) kegiatan inti; dan (c) kegiatan penutup. Kegiatan pendahualuan adalah kegiatan awal dalam proses pembelajaran yang terbagi atas tiga bagian (a) Orientasi; (b) Apersepsi; (c) Motivasi; (d) Pemberi Acuan. Selanjutnya kegiatan ini yaitu kegiatan pokok dalam proses pembelajaran yang terdiri atas lima bagian yaitu 
(a) Mengamati; (b) Menanya; (c) Mengumpulkan Informasi; (d) Mengasosiasi; (e) Mengkomunikasi. Dan yang terakhir adalah kegiatan penutup yaitu kegiatan penutup dalam proses pembelajaran yang terbagi atas 3 bagian yaitu (a) Menyimpulkan; (b) Umpan Balik; (c) tindakk lanjut.

Pada proses pembelajaran kurikulum 2013 menggunakan pendekatan saintifik yang terletak dalam kegiatan inti pembelajaran kurikulum 2013. Pendekatan saintifik adalah pendekatan yang wajib digunakan pada pembelajaran sekolah menengah, berdasarkan aturan kurikulum 2013. pendekatan saintifik pada kegiatan inti terbagi atas lima tahap yaitu mengamati, menanya, mengumpulkan informasi, mengasosiasi, mengkomunikasi.

\section{Model pembelajaran Kooperatif tipe STAD}

Model pembelajaran kooperatif tipe STAD memiliki beberapa sintak di mulai yang Pertama yaitu pendidik menyampaikan tujuan dan motivasi kepada peserta didik dan peserta didik menyimak apa yang di sampaikan oleh pendidik,Keduamenyajikan/menyampaikan informasi dengan bahan-bahan yang telah di persiapkan oleh pendidik sebelumnya. Ketiga mengorganisasi siswa dalam kelompok belajar, disini pesert didik di bentuk dalam kelompok sesuai dengan kemampuan peserta didik tersebut. Keempat pendidik membimbing kelompok bekerja dan belajar. Kelima Evaluasi, disini peserta didik di beri tes berupa Kuis oleh peserta didik yang dikerjakan secara individu. Keenam memberi penghargaan, perhargaan kelompok dapat dilakukan oleh pendidik dengan tahapan : menghitung skor individu, menghitung skor kelompok pemberian hadiah.

\section{Langkah-langkah model pembelajaran kooperatif tipe STAD pada kurikulum 2013}

Langkah Pertama pada model pembelajaran kooperatif tipe STAD yaitu meyampaikan tujuan dan motivasi terletak pada kegitan pendahuluan, Kedua yaitu menyajikan informasi yang terletak pada kegiatan inti dengan kegiatan mengamati dan menanya, Ketiga yaitu mengorganisasikan siswa dalam kelompok belajar yang terletak pada kegiatan inti degan kegiatan mengumpulkan informasi, Keempat yaitu membimbing kelompok belajar yang terletak pada kegiatan inti dengan kegiatan mengasosiasi, Kelima yaitu Evaluasi yang terletak pada kegiatan inti dengan kegiatan mengkomunikasi, Keenam yaitu penghargaan yang terletak pada kegiatan penutup.

\section{Kontribusi Model STAD dalam Mengembangkan Kemampuan Pemahaman Konsep}

Kontribusi antara model pembelajaran STAD dapat dilihat pada setiap langkah model STAD

a. Pada langkah pertama model STAD (menyampaikan tujuan dan motivasi) mampu mengasah indikator pemahaman konsep menyatakan ulang konsep yang telah dipelajari dan mengaitkan berbagai konsep dalam matematika maupun diluar matematika.

b. Pada langkah kedua (menyajikan informasi) mampu mengasah indikator pemahaman konsep mengklasifikasikan objek-objek berdasarkan dipenuhi tidaknya persyaratan yang membentuk konsep tersebut dan mengidentifikasi sifat-sifat operasi atau konsep.

c. Pada langkah ketiga model STAD (mengorganisasikan siswa kedalam kelompok belajar) mampu mengasah indikator pemahaman konsep mengklasifikasikan objek-objek berdasarkan dipenuhi tidaknya persyaratan yang membentuk konsep tersebut.

d. Pada langkah ke empat model STAD (membimbing siswa dalam belajar) mampu mengasah indikator pemahaman konsep menyatakan ulang konsep yang telah dipelajari dan mengklasifikasikan objek-objek berdasarkan dipenuhi tidaknya persyaratan yang membentuk konsep tersebut.

e. Pada langkah lima (evaluasi) mampu mengasah indikator pemahaman konsep menerapkan konsep secara logis, memberikan contoh dan non contoh dari konsep yang dipelajari, menyajikan konsep kedalam berbagai macam bentuk representasi matematis dan mengaitkan berbagai konsep dalam matematika maupun diluar matematika. 
f. Pada langkah ke enam model STAD (penghargaan) mampu mengasah indikator pemahaman konsep mengklasifikasikan objek-objek berdasarkan dipenuhi tidaknya persyaratan yang membentuk konsep tersebut.

\section{Pembahasan}

Model pembelajaran STAD bertujuan untuk menciptakan proses belajar aktif serta memungkinkan timbulnya sikap ketertarikan siswa untuk mengikuti kegiatan belajar mengajar secara menyeluruh. Memberikan kesempatan pada siswa untuk bertukar pendapat, menanggapi pemikiran siswa yang lain, saling bekerja sama, menggunakan media yang ada, akan dapat mengingat lebih lama mengenai suatu fakta, prosedur, definisi dan teori dalam matematika. Ini sesuai dengan prinsip pembelajaran yang ada pada kurikulum 2013.

Menurut (Isjoni, 2011). Model pembelajaran kooperatif tipe STAD merupakan model pembelajaran yang menekankan pada interaksi dan aktivitas diantara siswa untuk saling memotivasi dan saling membantu dalam memahami materi pelajaran demi tercapainya prestasi belajar yang maksimal, sehingga akan memberikan tanggung jawab individual kepada setiap siswa untuk berusaha secara maksimal supaya timnya mendapat penghargaan terbaik.

Dengan adanya belajar kelompok peserta didik dapat lebih memahami materi dengan penjelasan temannya sendiri, apalagi kelompok tersebut dibentuk secara heterogen dimana dalam setiap kelompoknya terdapat anggota dengan kemampuan belajar yang beragam mulai dari siswa dengan kemampuan tinggi, sedang, sampai rendah. Sehingga peserta didik dengan kemampuan belajar yang lebih tinggi bertanggung jawab untuk membantu teman satu kelompoknya untuk dapat lebih memahami materi.

Model pembelajaran STAD menekankan pada prestasi tim dalam proses pembelajaran setiap anggota kelompok saling bekerja sama dan memotivasi satu dengan yang lainnya. karena setiap kelompok akan berlomba-lomba untuk menjadi tim terbaik dan akan mendapat penghargaan nantinya. Karena di dalam model pembelajaran STAD ini terdapat kegiatan penghargaan kelompok, dimana kelompok yang berhasil mendapatkan skor tertinggi akan mendapatkan hadiah. Kegiatan inilah yang membuat siswa lebih termotivasi untuk memperbaiki kualitas belajar mereka. Ini sesuai dengan pendapat Slavin yaitu dalam model pembelajaran STAD, siswa di ajak untuk bekerja sama dalam kelompok, berpusat pada siswa dan guru hanya sebagai fasilitator. Apabila siswa sudah aktif, hal tersebut akan lebih mudah dalam kegiatan belajar mengajar. Dengan ini siswa tidak akan canggung untuk bertanya jika ada materi yang belum dipahami olehnya.

Kontribusi model pembelajaran STAD dalam mengembangkan kemampauan pemahaman konsep matematis dapat dilihat dari langkah-langkah pembelajaran model STAD yaitu:

Pada fase pembelajaran model STAD yang Pertama yaitu pendidik menyampaikann tujuan pembelajaran kepada peserta didik.

Pada tahap ini pendidik juga memberi motivasi kepada peserta didik dengan cara pendidik menyuruh peserta didik untuk mengingat materi sebelumnya dan menyampaikan kembali manfaat mempelajari metari tersebut dalam kehidupan sehari-hari.

Kegiatan menyampaikan tujuan dan motivasi oleh pendidik kepada peserta didik merupakan fase penting dalam proses pembelajaran. Kegiatan mengingat ini dapat memupuk indikator pemahaman konsep yang pertama yaitu menyatakan ulang sebuah konsep. Karena pada kegiatan ini dapat membantu peserta didik untuk menguasai dan mengingat materi yang sebelumnya telah dipelajari (Ernawilis, 2018) . Kegiatan menyampaikan motivasi dengan pendidik menyampaikan manfaat mempelajari materi tersebut dalam kehidupan sehari-hari dapat mengasah indikator pemahaman konsep yang ke tutjuh yaitu mengaitkan berbagai konsep kedalam matematika maupun dilauar matematika.

\section{Pada fase pembelajaran model STAD yang Kedua pendidik menyajikan dan menyampaikan informasi}

Hal ini dilakukan dengan memberikan materi yang akan dipelajari dalam bentuk lisan, tulisan, visual maupun dalam bentuk audio atau vidio, pada kegiatan ini peserta didik diminta untuk mengamati,membaca, mendengar, menyimak dan melihat tentang materi yang disajikan oleh pendidik (Padmadewi, 2017). setelah itu peserta didik disuruh mencari infomasi dari berbagai sumber yang berkaitan dengan materi yang sedang dipelajari. Pada sintak ini pendidik meminta peserta didik untuk menentukan dan mengelompokkan objekobjek dan sifat-sifat mengenai materi yang sedang disampaikan. Ini jelas bahwa pada langkah ini dapat mempupuk indikator indikator pemahaman konsep yang ke dua dan tiga yaitu mengklasifikasi objek berdasarkan dipenuhi tidak persyaratan yang membentuk konsep tersebut dan mengidentifikasi sifa-sifat operasi atau konsep. 


\section{Fase ketiga model pembelajaran STAD yaitu mengorganisasikan siswa kedalam kelompok belajar.}

Pada kegiatan ini pendidik akan mengatur dan menyusun peserta didik kedalam kelompok belajar sesuai dengan tingkat kemampuan peserta didik tersebut. Kegiatan ini dapat mengasah indiktor pemahaman konsep yang kedua yaitu mengklasifikasikan objek-objek berdasarkan dipenuhi tidaknya persyaratan yang membentuk konsep tersebut, karena pendidik mengajarkan peserta didik bagaimana mengelempokkan objek dengan tepat dan benar. Kemudian pada fase ini peserta didik akan saling tukar informasi atau peserta didik yang memiliki kemampuan tingkat tinggi membantu teman kelompoknya dalam memahami konsep yang dipelajari. Sedangkan peserta didik yang berkemampuan rendah lebih leluasa menanyakan materi yang belum dipahami kepada temannya yang memahami materi dengan baik (Puspa, 2019). Sehingga semua anggota kelompok dapat memahami materi dan tugas yang diberikan oleh peserta didik. Karena kerja sama pada langkah ini sangat dituntut untuk bisa menjadi tim terbaik dengan skor nilai yang tinggi.

\section{Fase yang keempat yaitu membimbing kelompok bekerja dan belajar.}

Pada fase ini pendidik memberi penjelasan, menuntun peserta didik untuk mengelola informasi yang telah mereka dapat dengan cara menyuruh peserta didik untuk mengklasifikasi benda-benda, membedakan mana yang contoh dan bukan contoh dan mengaitkannya dalam matematika maupun diluar matematika ini sesuai dengan indikator pemahaman konsep nomor satu dan dua yang ada pada Permendikbud no 58.

\section{Fase ke lima yaitu evaluasi (kuis).}

Peserta didik mempersentasikan hasil diskusinya. Ini dapat meningkatkan indikiator pemahaman konsep pada nomor empat, lima, enam, dan tujuh. Karena pada kegiatan ini peserta didik saling tukar informasi kepada teman-temanya dari kelompok lain, dan antar anggota kelompok saling bekerja sama dan memotivasi (Septian, 2020). Kemudian pendidik memberikan soal kuis secara individu kepada peserta didik dan tidak boleh saling membantu kemudian pendidik menghitung skor rata-rata dari setiap anggota kelompok kemudian salah satu peserta didik menyimpulkan materi yang telah di pelajari.

\section{Fase yang keenam yaitu penghargaan}

pendidik memberikan penghargaan kepada tim yang memiliki skor rata-rata paling tingggi, pada kegiatan ini pendidik mengajarkan pendidikan karater yaitu bagaimana mengelompokkan tim mana yang terbaik yan sesuai dengan kriteria untuk menjadi tim terbaik. Ini dapat mengasah indikator pemahaman konsep yang kedua yaitu mengklasifikasikan objek-objek berdasarkan dipenuhi tidaknya persyaratan yang membentuk konsep.

Model pembelajaran STAD memiliki kelebihan, namun model pembelajaran STAD juga memiliki kelemahan yaitu peserta didik yang berkemampuan tinggi dalam kelompok akan kurang bersemangat dalam belajar dan apabila timbul sifat individualisme pada peserta didik yang memiliki kemampuan tinggi maka tujuan pembelajaran tidak akan tercapai karena peserta didik yang berkemampuan rendah akan kurang memahami materi yang sedang dipelajari. Untuk mengatasi kelemahaman tersebut tindakan yang harus diambil oleh seorang pendidik adalah menjelaskan kepada peserta didik bahwa kerja sama itu adalah kunci dari model pembelajaran STAD dan untuk menjadi tim terbaik, tim tersebut harus memperoleh skor rata-rata teringgi yang di dapat dengan cara kerja sama dalam memahami materi pelajaran. Cara tersebut peserta didik akan berlomba-lomba untuk menjadi tim terbaik dan seluruh peserta didik akan menjadi lebih bersemangat.

Berdasarkan uraian di atas dapat disimpulkan bahwa model pembelajaran kooperatif tipe STAD cocok untuk meningkatkan pemahaman konsep matematis peserta didik dengan kata lain model pembelajaran kooperatif tipe STAD berkontribusi terhadap kemampuan pemahaman konsep matematis peserta didik.

\section{SIMPULAN}

Berdasarkan hasil penelitian maka dapat disimpulkan bahwa model pembelajaran kooperatif tipe Student Teams Achievment Division (STAD) yang memiliki enam langkah beerkontribusi terhadap kemampuan pemahaman konsep matematis. Dan setiap langkah pada Model pembelajaran STAD dapat mengembangkan indikator pemahaman konsep yangg ada pada Permendikbud No 58 tahun 2014. 


\section{REFERENSI}

Ernawilis. (2018). Penerapan Model Pembelajaran Kooperatif Tipe STAD Dalam Meningkatkan Pemahaman Konsep Matematika Materi Himpunan Pada Siswa Kelas VII 4 SMP Negeri 13 Tahun 2016.Instructional Development Journal, 1(1)

Handayani, Suci. (2019). Model Pembelaaran Speaking Tipe STAD Yang Interaktif Fun Game Berbasis Karakter. Sidoarjo: UWAIS INSPIRASI INDONESIA

Isjoni. (2011). Cooperative Learning: Mengembangkan Kemampuan Belajar Berkelompok. Bandung: Alfabeta

Murnaka, Nerru Pranuta dan Rika Itho Manalu. (2018). Penerapan Model Pembelajaran Student Team Achievement Division untuk Meningkatkan Kemampuan Pemahaman Konsep Siswa. Jurnal Pendidikan Matematika, 6(3), 318.

Padmadewi, Nyi Nyoman, Luh Putu Artini, Dan Dewa Ayu Eka Agustini. (2017). Pengantar Microteaching. (Depok : Rajawali Press

Peraturan Menteri Pendidikan Dan Kebudayaan Republik Indonesia No. 58 Tahun 2014. Tentang Kurikulum 2013 Sekolah Menengah Pertama/Madrasah Tsanawiyah

Puspa, Nesha Aprilia, Sugeng Sutiarso, dan Rini Asnawati. (2019). Pengaruh Penerapan Pembelajaran Kooperatif Tipe STAD Terhadap Pemahaman Konsep Matematika Siswa. Jurnal Pendidikan Matematika, 7(3), 425

Septian, Ari, Deby Agustina Dan Destysa Maghfirah . (2020). Model Pembelajaran Kooperatif Tipe Student Teams Achievement Division (STAD) untuk Meningkatkan Pemahaman Konsep Matematika. Mathema Journal, 2(2), 12

Slavin, Robert . (2008). Model Pembelajaran Kooperatif. Padang: UNP

Soewarso. (1998). Menggunakan Strategi Komparatif Learning di dalam Pendidikan Ilmu Pengetahuan Sosial. Edukasi

Trianto. (2007). Model-Model Pembelajaran Inovaif Berorientasi Konstruktif . Jakarta : Prestasi Pustaka

Yanuar dkk. (2019). Penerapan Model Student Teams Achievement Division Terhadap Kemampuan Pemahaman Konsep Matematika Siswa Kelas VIII. Jurnal Pendidikan Matematika, 7(1),60 